Article

\title{
Roaming through the Maze of Maize in Northern Ghana. A Systems Approach to Explore the Long-Term Effects of a Food Security Intervention
}

\author{
Ellen Mangnus * and A.C.M. (Guus) van Westen \\ Department of Human Geography \& Spatial Planning, Utrecht University, 3508 TC Utrecht, The Netherlands; \\ A.c.m.vanWesten@uu.nl \\ * Correspondence: e.p.m.mangnus@uu.nl; Tel.: +31-(0)30-253-2746
}

Received: 24 August 2018; Accepted: 28 September 2018; Published: 10 October 2018

check for updates

\begin{abstract}
Central to food security interventions in Sub-Saharan Africa stands the value chain approach. The underlying idea is that connecting farmers to input and output markets and sources of knowledge and technology will enhance their food security status. In spite of positive impacts measured in especially food supply, there is scant evidence of the long-term effects on food security. For a better grasp of the impacts of a maize value chain intervention in North Ghana, we have experimented with an approach that focuses on interactions and feedback loops between the value chain and its local context. Such approach allowed us to identify dynamics that affect food security in the long run. In the case of Northern Ghana farming systems, household income and diets are increasingly dependent on maize, which increases risk of food insecurity in case of climate setbacks or market shocks. The exercise reveals how a linear value chain approach obscures the dynamic effects cascading from the intervention that may actually hamper food security in the long run. A systems approach may help to better grasp the consequences of external interventions at the local level.
\end{abstract}

Keywords: value chain analysis; systems approach; private sector led development; food security; causal loop diagram

\section{Introduction: In Need of a Novel Approach to Food Security}

The period 2000-2015 stands out for an unparalleled awareness of the global food security challenges. "By 2050 the world needs to feed 9 billion people" has become one of most cited adages in the international policy arena. "End hunger, achieve food security and improved nutrition, and promote sustainable agriculture" goes the second of the seventeen SDGs. It is in this spirit that an increasingly diverse constellation of actors, such as agribusinesses, philanthropists, social entrepreneurs, and other companies aside public agencies and NGO's are intervening in agriculture in the Global South under the stated goal of contributing to food security [1].

Central in these interventions stands the value chain approach. A value chain encompasses the sequence of value-added activities that firms and workers accomplish to bring a product from its conception to its end use [2]. The value chain approach stems from the global commodity chain approach that was used by development scholars as an analytical tool to study inequalities in global trade [3-8].

Remarkably, over the years, the approach has been transformed into an instrument for intervening in markets $[9,10]$. By mapping the key actors involved in a production process and identifying and removing bottlenecks between producers, traders, processors, transporters, banks, and other actors, development practitioners assume that farmers can be lifted out of an assumed stagnant agricultural sector, isolation from the market and finally poverty. In other words: The value chain is now presented 
as a 'route' to the market [9-17] and more recently also as 'a route to food security'. The approach occupies a central place in development policy and practice.

In this paper, we develop the argument that value chain interventions fall short of overcoming long-term adverse effects on food security. A narrow focus on the impacts for actors within the chain obscures extra chain effects that might have repercussions on food security in the long run. By taking a systems approach to study the interaction between a maize value chain in Northern Ghana and its local spatial context this study aims to gain a better understanding of the long-term food security effects. Our study is underpinned by two central arguments. Firstly, it contends that a value chain intervention can help isolated producers improve their food security situation in the long run. The second argument draws inspiration from systems approaches, to highlight that value chains are contoured by a spatial context that has its repercussions and feedbacks to the value chain and to food security in the long run. Three research questions are guiding our study: First: What changes in agriculture and food security over the past ten years have people in the research area experienced? Second, how do these changes relate to or interact with the value chain intervention? Third, what are the long-term effects of the value chain intervention on local food security?

The article is divided into four parts. The first (Section 2) elaborates the current food security narrative and its corresponding intervention logic. Section 3 details the way we approach food security. Section 4 introduces the case study and its context. In Section 5 the methods used for data collection and data analysis are presented and Section 6 builds on the case study to respond the first two research questions. In Section 7 we consider the wider implications for local food security. We finalize our paper with a reflection on the value of systems approaches in Section 8 .

\section{Shifting Conceptualisations of Food Security and the Role of the Private Sector}

The year 2008 marked a shift in the position of food security on the global policy agenda. Price hikes in international commodity markets took thousands of people in the Global South to the streets, as they were facing difficulty in obtaining food. Policy makers realized that this basic human need was under pressure and that food scarcity could drive social unrest and instability.

What followed was a shift in strategies governments pursued to curb food insecurity. Since African independences and the World Food Conference (1974) food security was conceptualized as a question of national self-sufficiency [18]. The objective for African countries was to meet their national calorie needs [19]. To achieve this, it was believed, agricultural production needed to be spurred. Global support was given to African countries to heavily invest in agricultural extension, improved seeds and pesticides and fertilizers, the so called Green revolution packages [20]. Focus was on efficiency, productivity and rationality [21].

Food insecurity persisted in the global South and when Sen [22] introduced his influential theory on food entitlement, the perspective on food security changed: From an emphasis on the 'natural' causes of hunger to a focus on the wider political and socioeconomic context $[23,24]$. Case studies revealed situations of starvation in countries in which plenty of food was available $[25,26]$. The policy focus changed towards approaches that focused on food distribution and access for vulnerable people [27-29]. Not food availability, but access to food, was the issue. Sen's approach was adopted by an emergent neoliberalism $[20,30]$. The dominant idea was that access to food could be improved by higher incomes and better developed agri-business sectors. The new paradigm predicated that African countries had to specialize in crops in which they had a comparative advantage. International institutions pressured African states stop intervening in agriculture and leave agricultural research and development, input dissemination and extension services to free market forces. As a consequence, attention was shifted from food crops to high-value export crops, such as cocoa and coffee [31].

The food crisis of 2008 undermined this prevailing paradigm. The higher income approach succumbed to a refocus on food production as the way to solve global, and especially African, food insecurity $[21,32,33]$. Different from the earlier approaches focusing on food production in 
today's interventions a central role is assigned to the market. Underlying the interventions is the idea that farmers need to be part of global value chains [20].

To a large extend this can be explained by increased private sector engagement in agriculture in Sub Saharan Africa [20]. The food crisis of 2008 triggered a wave of foreign, private sector investments in agriculture in developing countries. Many of the Sub-Saharan African governments welcomed these foreign direct investments (FDI) and other forms of financing. They envisioned the investments as a way to modernize their agriculture, spur growth, and diminish national food insecurity. Considering declining official development budgets in the Global North, donors, and governments alike warmly welcomed private participation and investment [34,35]. They assumed that FDI in the form of commercial agriculture would also create opportunities for local smallholders in terms of productivity increase, value addition, enhanced market access, and income generation. Both private and public actors embraced the value chain concept as a way to ensure that opportunities could be seized by disadvantaged actors in the market.

\section{Taking a Systems' Approach to Study Food Security}

This paper departs from an unease with the positioning of value chain interventions as means to improving food security. We question whether the singular focus on vertical relations within the value chain is a sufficient basis for an adequate understanding of how market integration of smallholders impacts food supply and access at the local level. As such, this contribution is positioned in a long and ongoing debate on food security impacts of agri-business development. Since long researchers have tried to study the effects of commercial agriculture on smallholder livelihoods in general (See for example $[26,36,37]$ and the effects of certain business models e.a. contract farming, out grower models or plantation estates, in specific [38-43]. Micro-economic case studies on direct impacts such as farmer productivity and income of agri-business interventions abound (See for example: [44-47] For the impact of contract farming and [48-50] for the impact of estate farming). A number of studies focusses specifically on the effects of commercial agriculture on smallholder food security. Anderman et al. [51] found a negative correlation between engaging in oil palm and cocoa and farmers' food security situation in Ghana. On the other hand, Kuma et al. [52] found positive relations between smallholder coffee farming and food security in Ethiopia. Similarly, Negash et al. [53] found a positive effect of household participation in castor bean production for biofuels on food caloric intake in Ethiopia.

Critics have denounced these types of linear assessments; they plea for attention to how these schemes intersect with existing agrarian social structures [40]. For example, Vicol [54], in his study to contract farming in India, rejects how impact assessments in general lump farmers in two homogenous groups: one that is part of a scheme and another, a control group, that is not part of the scheme. In his case study, contract farming provides distinct opportunities to different social groups within rural villages. According to Vicol [54], "The implications of contract farming for accumulation and differentiation are shaped by the historical structures of existing agrarian landscapes (social, economic, political, and institutional), local livelihood patterns and the dynamics of the contract scheme." $\mathrm{Xu}$ [55] encountered similar findings in her study on the impact of expanding tea plantations on local communities in China. In line with research of feminist economists on the gendered impacts of agribusiness development in developing countries, Tsikata and Yaro [56] plea for a recognition of diversity within communities in order to understand the impacts of agribusiness interventions. Underlying value chain interventions is the assumption that they contribute to improved productivity, and as such, local food availability or to enhanced income which enables people to buy food. Several assessments, however, show that that these linkages are not clear-cut [57]. In a study of Gomez and Ricketts, [58] changes in food value chains have different food security implications for different social classes in developing countries.

Scholars studying clusters and networks, such as Gibbon and Ponte [14], Graef et al. [59], Lowitt et al. [60], Riisgaard et al. [61], Ouma et al. [10] argue that value chain interventions neglect horizontal relations shaped by institutional, social, and historical contexts that are of influence on the 
final impact. Case studies of Fold [13], Murphy and Schindler [62], and Neilson and Pritchard [63] show that outcomes of global value chains are site-specific and strongly depend on local mechanisms of inclusion and exclusion. Vice versa this local social context also affects the composition and performance of the value chain.

Following these critical scholars we use a context sensitive approach, a systems approach, to assess the effects of a value chain intervention on local food security. When referring to a 'systems approach', we mean an approach that places a research phenomenon in its environment and studies the relationship between the two. Examples of recent popular systems approaches in development are landscape approaches and food systems approaches. A landscape approach is an integrated framework to address complex challenges that transcend environmental, economic, social, and political boundaries $[64,65]$. A food systems approach provides a framework for systematic analysis of the two-way interaction between the range of value chain activities, food security outcomes and the social and environmental context in which the intervention takes place [66-71].

Central to these approaches is the multi functionality of the local landscape or ecological system, e.a. agriculture, water, forest, people, and the impacts and trade-offs of production activities. At the same time they pay attention to how this local landscape influences the way value chain activities are performed. Elementary in these approaches is the focus on the relationships and feedback loops between the value chain and its context [59,72]. It is, especially, this focus on interaction and feedback between an intervention and its context', that we take from these approaches. For operationalizing our systems approach we use a Causal Loop Diagram. A Cuasal Loop Diagram is a system modeling technique utilized to qualitatively reflect on variables and interrelationships [73].

The remainder of this paper presents the empirical case of maize in Northern Ghana. Maize is a major crop in this relatively poor part of the country and as such the logical target of interventions aiming at enhancing local food security.

\section{Setting the Context: Ghana and the Maize Value Chain}

Ghana showcases a country that attracts and encourages agri-business development with the overarching objective of enhancing national food security. Agriculture is largely smallholder-based Yaro et al. [43], 80\% of the land is held under customary land tenure [56,74]. The governments' underlying idea is that agriculture needs to be modernized in order to be able to respond to national food demand. It aims to achieve this by stimulating private actors to engage with and lift the potential of the thousands of small scale farmers. Ghana has a long history of foreign engagement in commercial agriculture. Under pressure from the Worldbank and IMF, Ghana was forced to accept liberalization and privatization measures in the 1980's. This led to a deeper integration of the economy into global commodity chains with foreign direct investment as a key instrument. Mines and plantations were privatized and land was sold to export-oriented agri-business [75]. The food crisis in 2007-2008 led to another round of foreign engagement in commercial agri-business. Special focus was on jatropha, rice, maize, and fruits, with plans for further expansion of oil palm production for biofuel [76].

Since 2007, the value chain approach stands central in the country's agricultural and economic policy [10]. This is exemplified by the governments' private sector investment plan for agricultural development (GASIP) formulated in 2012. GASIP consists of four strategies: (i) Linking smallholder farmers to agribusinesses to enhance pro-poor growth; (ii) nationwide scaling up of a successful value chain investment approach; (iii) promoting and mainstreaming climate change resilience approaches in Ghana, in particular in the Northern regions; and (iv) knowledge management, harmonization of intervention approaches and policy support (www.gasip.org). Numerous donors intervene in Ghana by way of value chain projects (see Table 1). The case study we selected exemplifies such a typical project. Our study focuses on the Upper West Region. With 70.7 percent of its population below the poverty line in 2013 this is Ghana's poorest region (Ghana Statistical Service 2014). According to the Ghana Demographic and Health Survey $(2014,22 \%$ of children under the age of five were 
malnourished (stunted). Agro-ecologically, it belongs to the West African semiarid savannah, a zone with a unimodal rainfall pattern with one wet and one dry season per year [77].

Historically poverty relief programs in Upper West Region have focused on enhancing productivity through what was framed as 'modernization of agriculture', often emphasizing the use of fertilizers, hybrid seeds and irrigation (See for examples: [78-80]). Since the early 2000's, the focus shifted to 'modernizing agriculture to access global markets. Most development programs are rolled out by public-private partnerships. Typical activities include training farmers in new technologies, agri-business organization, quality control and standards, value added processing, and linking farmers with agro-industries [81].

The following table gives an overview of the extensive number of value chain projects in the Northern regions.

In hindsight all interventions, both private and public, narrowly focused on stimulating production and linking farmers to both in and output markets by means of value chain interventions. Our case study, the so-called Masara N'arziki intervention provides a compelling case to explore food security issues. First, because the set-up of the intervention is in line with the dominant development approach, in which food security ambitions are to be achieved by means of private sector engagement and a value chain approach, that promotes the use of inputs such as fertilizers, seeds, and pesticides and linking farmers to high-value markets [82]. Second, because maize is a major staple crop in Northern Ghana, shifting towards becoming a major cash crop [83]. Food security effects reach beyond the actors directly involved in the value chain. What does this food crop-cash crop transition mean for both the population and the landscape? 
Table 1. Overview of interventions in North Ghana following a value chain logic.

\begin{tabular}{|c|c|c|c|c|}
\hline No. & Organization & Project & Objective & Timeline \\
\hline 1 & IFAD & $\begin{array}{l}\text { Land Conservation and } \\
\text { Smallholder Rehabilitation } \\
\text { Project (LACOSREP II) }\end{array}$ & Smallholder farmers focusing on crops and livestock, dams and irrigation & 2000-2006 \\
\hline 2 & $\begin{array}{l}\text { Millennium Development } \\
\text { Authority (MiDA) }\end{array}$ & $\begin{array}{l}\text { MiDA Agricutural Credit } \\
\text { Program (ACP) }\end{array}$ & $\begin{array}{l}\text { To reduce poverty through economic growth by enhancing the profitability of } \\
\text { agricultural production; through improving business and technical services that } \\
\text { support commercial agriculture expansion; reduce transportation costs affecting } \\
\text { agricultural commerce; and strengthen rural institutions. }\end{array}$ & 2007-2012 \\
\hline 3 & IFAD/AfDB & $\begin{array}{l}\text { Northern Rural Growth } \\
\text { Programme (NRGP) }\end{array}$ & $\begin{array}{c}\text { To increase income of small scale producers and processors in rice, maize, sorghum } \\
\text { and soya value chain. }\end{array}$ & 2007-2015 \\
\hline 4 & $\mathrm{ACDI} / \mathrm{VOCA}$ & USAID/ADVANCE I Project & $\begin{array}{l}\text { Improving the competitiveness of the maize, rice, and soybean value chains through } \\
\text { a value chain approach, where smallholder farmers are linked to markets, finance, } \\
\text { inputs, equipment, and information through larger commercial farmers and traders } \\
\text { who have the capacity and incentive to invest in smallholder production. }\end{array}$ & 2009-2014 \\
\hline 5 & $\mathrm{IFAD} / \mathrm{AfDB} / \mathrm{WB}$ & $\begin{array}{l}\text { Rural and Agricultural Finance } \\
\text { Programme (RAFIP) }\end{array}$ & $\begin{array}{l}\text { To provide poor rural people and smallholder farmers with improved access to } \\
\text { financial services, technical assistance and risk management instruments. It thus } \\
\text { strengthens agricultural value chains and provides smallholder farmers with an } \\
\text { opportunity to maximize the productive potential of their lands. }\end{array}$ & 2010-2016 \\
\hline 6 & IFDC & $\begin{array}{l}\text { Agricultural Value Chain } \\
\text { Mentorship Project (AVCMP) }\end{array}$ & $\begin{array}{l}\text { Contributing to the Government of Ghana's objectives of achieving food security } \\
\text { and converting the country's agriculture sector into an agro-industrial economy by } \\
\text { transforming agricultural value chains into a highly productive, efficient, } \\
\text { competitive and sustainable system by linking smallholder farmers, agro-dealers } \\
\text { and small and medium enterprises (SMEs) to service providers such commercial } \\
\text { banks, agro-dealers and seed producers. }\end{array}$ & 2011-2014 \\
\hline 8 & $\begin{array}{l}\text { Mennonite Economic } \\
\text { Development Associates } \\
\text { (MEDA) }\end{array}$ & $\begin{array}{l}\text { Greater Rural Opportunities for } \\
\text { Women (GROW) Project }\end{array}$ & $\begin{array}{c}\text { Using market-driven approaches, MEDA' s Greater Rural Opportunities for Women } \\
\text { (GROW) project focuses on improving food security for families in Northern Ghana } \\
\text { by assisting women farmers to grow more soybeans and forge market links that will } \\
\text { increase incomes. Soybeans offer multiple advantages. }\end{array}$ & 2012-2018 \\
\hline 9 & Masara N'Arziki & Sustainable maize project-SMP & $\begin{array}{l}\text { To support maize farmers to enhance productivity and quality through the use of } \\
\text { improved inputs, improved technology, capacity building and access to markets }\end{array}$ & 2013-April 2018 \\
\hline
\end{tabular}


Case Study: Involving Farmers in the Maize Value Chain to Enhance Food Security

Masara N'arziki farmers association was created in 2009 by two agribusiness companies, Wienco and Yara [81]. Both Wienco and Yara are partly foreign owned. Their mission fits well with the governments' ambition to modernize agriculture. Wienco is active in Ghana since 1979, the company has a long history in trading cocoa and is currently also involved in trading commodities such as rice, maize and cotton. Its subsidiaries provide smallholders with agricultural services and inputs. The company's mission is among other things to "improve the productivity of small farmers in Ghana" (http:/ / wienco.com/Site/subsidiaries.html), Yara Ghana was established in 2007 “ . . . to increase the productivity of Ghanaian farmers" (http:/ / www.yara.com.gh/about-yara/about-yara-local/). Masara N'arziki means 'Maize for prosperity'.

The establishment of Masara N'arziki was intended to help the companies expand their market for inputs and fertilizers and maize procurement and at the same time contribute to agricultural development in the North.

The theory of change underlying the intervention of Masara N'arziki was that by increasing crop yield and at the same time providing farmers with a market, income would increase and enable the households to move out of poverty and food insecurity [84]. Masara N'arziki is managed by a team of professionals and increased its membership from 1250 farmers in 2009 to 10.000 in 2015 in the three Northern provinces of Upper West, Upper East, Northern region, and parts of Brong Ahafo [85].

The business model worked as follows. The association committed to deliver inputs and extension services on credit, which farmers had to pay back in maize after harvest. The input package farmers receive consists of fertilizer, herbicides, and hybrid maize seeds from Wienco. These varieties yield more than the open-pollinated maize variety that currently prevails. However, they also required more fertilizer [86,87]. Until Pannar 53 was officially launched in Ghana, Masara N'arziki was the only channel through which farmers could acquire the seed [87]. The contract stipulated that farmers sell their excess produce to Masara N'arziki to supply poultry farms and breweries in the South of Ghana. However in practice this was rarely done (Interviews; [88]). Reasons given by farmers is that the timing of purchase by the association is not aligned with members' needs of instant cash after the harvest. Except for the years in which the price offered by Masara N'arziki was much higher, the majority of the farmers always sold individually to itinerant travelers.

Over time Masara N'arziki's business model has undergone several changes. For example, early group contracts were replaced by contracts with individual farmers as it turned out that defaults by some group members harmed the interests of others (Interview Manager). Moreover, the association stopped working in communities with a high default rate. Several evaluations and assessments [86,89] found positive results in terms of adoption of farming practices, yield and income. According to Al-Hassan et al, [89] findings 79\% of the farmers working for Masara N'arziki had enough food year round as compared to $58.5 \%$ of farmers not participating. Despite these positive results, interviews suggest that the dynamics sparked by the value chain intervention might hamper local food security in the long run.

\section{Methodology}

This article studies how the Masara N'arziki value chain intersects with the surrounding agrarian landscape. The aim of this exploratory case study is twofold: First to enhance understanding of the effects of a value chain intervention targeting productivity and marketing on food security in the long run. Second, to assess the effectiveness of prevailing models of market-led food security interventions

\subsection{Data Collection}

This study scrutinizes a case study. The case study method was found to be most suitable for researching a contemporary phenomenon in a dynamic context, dynamics that were not always easy to distinguish from the phenomenon [90]. Interventions such as commercial farming projects can be 
difficult to discuss separately from the agrarian political economy in which they are located, as the context itself is also undergoing profound changes [43]. Three qualitative data collection techniques were considered useful to learn about how people experience an external intervention: Focus group discussions, key informant interviews, and in-depth interviews [91].

The fieldwork took place in August 2017 in the Sissala East district. Sissala East was selected because it's reputation for being the maize basket of North Ghana. The first step was the elaboration of a list of most important changes in agriculture, as perceived by the local population. Fifteen semi-structured interviews with farmers and four focus group discussions were used to collect the data. In the focus groups we discussed whether and how the changes related to the maize value chain intervention. The sampling for the interviews was accidental, farmers were approached during field visits, community meetings and market days. A diversity of hours during the day, distances from the road and the district capital and age groups was considered. The participants for the group discussions were purposively sampled. Technical officers of Masara N'arziki Tumu selected four communities that differed in distance to the district capital of Tumu, presence of other interventions and default rate. Together the four covered the main differences of the region in terms of accessibility to the road and markets, productivity and social capital. Group leaders in the communities invited farmers. We listed all the changes that were referred to by at least $70 \%$ of the interviewees. Triangulation with key resource persons (three traders, three agro dealers, six staff members Masara N'arziki, three NGOs, and two local officials) confirmed farmer perceptions. Subsequently, findings were supported by literature and existing meteorological and land use data.

\subsection{Data Analysis}

As we were interested in the interaction between the value chain and its local context, specifically in the feedback mechanisms that could potentially impact food security in the long term, we sought for a tool that could help us identify and systematize these interaction effects. We found a suitable method in the causal loop diagram. A causal loop diagram is a tool for tracing cause and effect chains [92-94]. The diagrams uncover processes of feedback and can therefore help clarify less visible and slower changes in a system. A system can be any regularly interacting or interdependent group of units, ranging from an organization, to a public health system to a landscape. Causal loop diagram is still little used in development studies [95]. The construction of a causal loop diagram involves the following steps:

1. Creating variable names. The first step is to identify the variables that are important to the issue, in our case food security.

2. The next step is to fill in the links between the variables. If variable $B$ moves in the same direction as variable $A$, the link from variable $A$ to $B$ will be a straight line (Figure 1). If variable $B$ changes in a direction opposite of $A$ (i.e., as A increases, B decreases), the link from A to B is dotted (Figure 2).

3. The last step is to determine the type of behavior the loop will produce. This can be either reinforcing or balancing. In a reinforcing loop, change in one direction leads to more change. For example, money in a savings account generates interest, which leads to an increase in the savings account and leads to more interest. We label reinforcing loops with an R (Figure 1). 


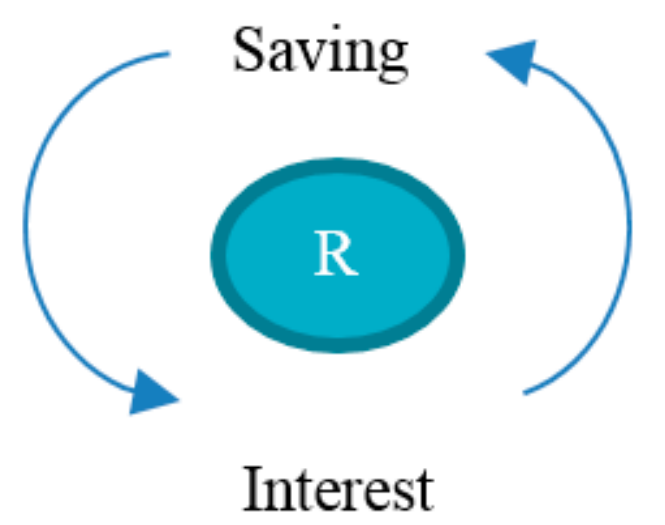

Figure 1. Example of variables connected by causal links and feedback loops.

Balancing loops are the opposite. Change in one direction leads to change in the opposite direction. For example, when one eats, hunger is appeased. We label the loop with a B (Figure 2).

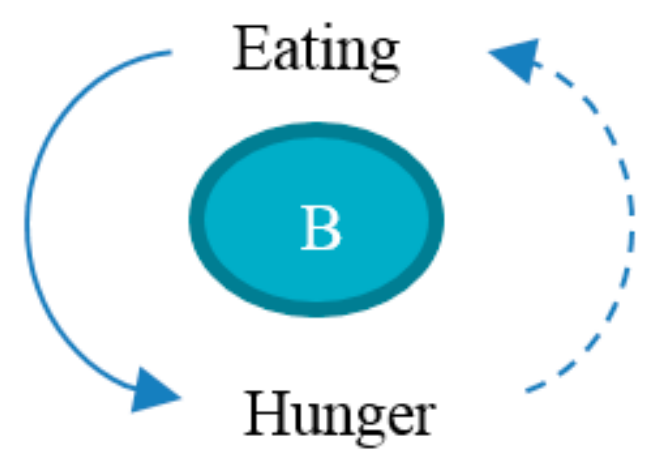

Figure 2. Example of variables connected by causal links and feedback loops.

A causal loop diagram helped us to assemble the seemingly loose observations into a systematized view of the whole and highlights the feedback loops between the value chain and its agrarian context. This subsequently helped us to identify potential long-term effects on food security. The drawing of the diagram was the work of the researchers, however the variables are based on local perceptions.

\section{Findings: Perceptions on the Effects of Modern Maize Cultivation}

6.1. What Changes in Agriculture and Food Security over the Past Ten Years Have People in the Research Area Experienced?

Interviews and group discussions with farmers on the major changes perceived in agriculture over the last ten years led to the following overview (in random order). These changes will be the variables of our causal loop diagram.

- Labor (decreasing availability)

- Agricultural practices (Increased mechanization)

- Modern farm in puts (increased use)

- Natural resources (decreasing soil fertility)

- Commercialization (Enhanced marketing)

- Climate (increased rainfall)

6.2. How Do These Changes Relate to or Interact with the Value Chain Intervention?

In this section we draw the links between the value chain intervention and the agrological and socio-economic dynamics listed by the farmers. Following step 2 of the creation of the causal loop diagram, we will label the loops as reinforcing or balancing. 


\subsubsection{Labour}

Listed by all farmers as a major shift in agriculture was the decreasing availability of labor. Whereas, in the past, the hands to help out during peaks, like planting and harvesting, were numerous, now farmers spend long days alone on the fields to get work finished.

Respondents mentioned several explanations for this decline. The abolishment of child labor seems to have accounted for a significant share. Since 2005 the government of Ghana strictly implemented compulsory education for children till the age of 15. As one farmer phrased: "Since Plan Ghana came in the area, in 2006, they planted in our head that children have to go to school. Our children were responsible for the bullocks. As a consequence all the farmers sold their bullocks." The decrease of the number of plowboys was also found in a study to animal traction by IFPRI [96]. The census of 2012 [97] confirms that households reported that approximately $91 \%$ of school-age children (6 to 15 years) are regularly enrolled in school.

Other farmers reported the erosion of social capital and collective labor in the community. "When we were young, we would help each other, we would collectively harvest each community member's land, now each assistance has its price. We are forced to manage by ourselves" (Interview) and "In the past, when a man would marry, he would call his age-group and brothers to harvest the land of its parents in law. Nowadays agriculture has become individualistic." (Interview) The increasing dependence on money for maintaining a livelihood has made people more individualistic, was the local clarification for this shift (confirmed by a study of [98]). Other studies [99,100] show how this shift is specifically disadvantageous to the poorer farmers that do not have the means to hire labor.

A number of farmers mentioned that youth, specifically sons, migrate in search of a better life elsewhere. Migration from Upper West region is of all times, however it is no longer limited to the off-season period. Rademacher-Schulz et al. [77] found that also in rainy periods migration has increased, sons of farmers work in the mines in South Ghana, as laborer or share-cropper on farms in the Brong Ahafo region. Migration patterns from the Upper West region have shifted from temporary seasonal migration to permanent migration. This new trend is typified by the establishment of farms by migrants in certain parts of southern Ghana [101]. A recent study by WFP and MoFA [102] indicates that 34 percent of households in the Upper West region had at least one member as a migrant worker residing in another part of the country. These migrants send food and cash back home to sustain their families [103-105] In his study to mechanization, Diao et al. [99] mentions urbanization in Ghana as one of the driving forces of decreasing rural labor.

According to the farmers there is a strong link between the decline of labor availability and the embrace of the maize intervention. Labor scarcity is a major driver of the shift towards a maize dominated farming system. Compared to other crops cultivated in the region, such as millet and sorghum, maize requires less labor, as phrased by one farmer: "Maize is an easy crop. With millet you scratch your skin, no one wants to harvest it anymore. You can harvest hundred maize bags in the same time you can harvest only five millet bags." (Interview).

Laborers seem to have a preference for maize above other crops. For example during the harvest season women groups from the Kassena-Nankana District come to Upper-West to offer labour services. Previously, these women would harvest any crop; nowadays, they are specialized in maize. As one farmer mentioned: "Maize is the easiest and the earliest crop to harvest, the woman groups travel around and do not want to stay any longer for millet or groundnuts As there are enough maize fields to harvest, there is no reason for them to take on the more difficult groups" (Interview).

The decline in hands to work the land explains why farmers shift from intensive labor food crops to a less intensive crop such as maize. As such, the interaction between labor and maize cultivation is negative. The less labor available, the more attractive maize will be. On its turn maize, cultivation encourages individual farming. As Figure 3 shows, the loop is reinforcing. 


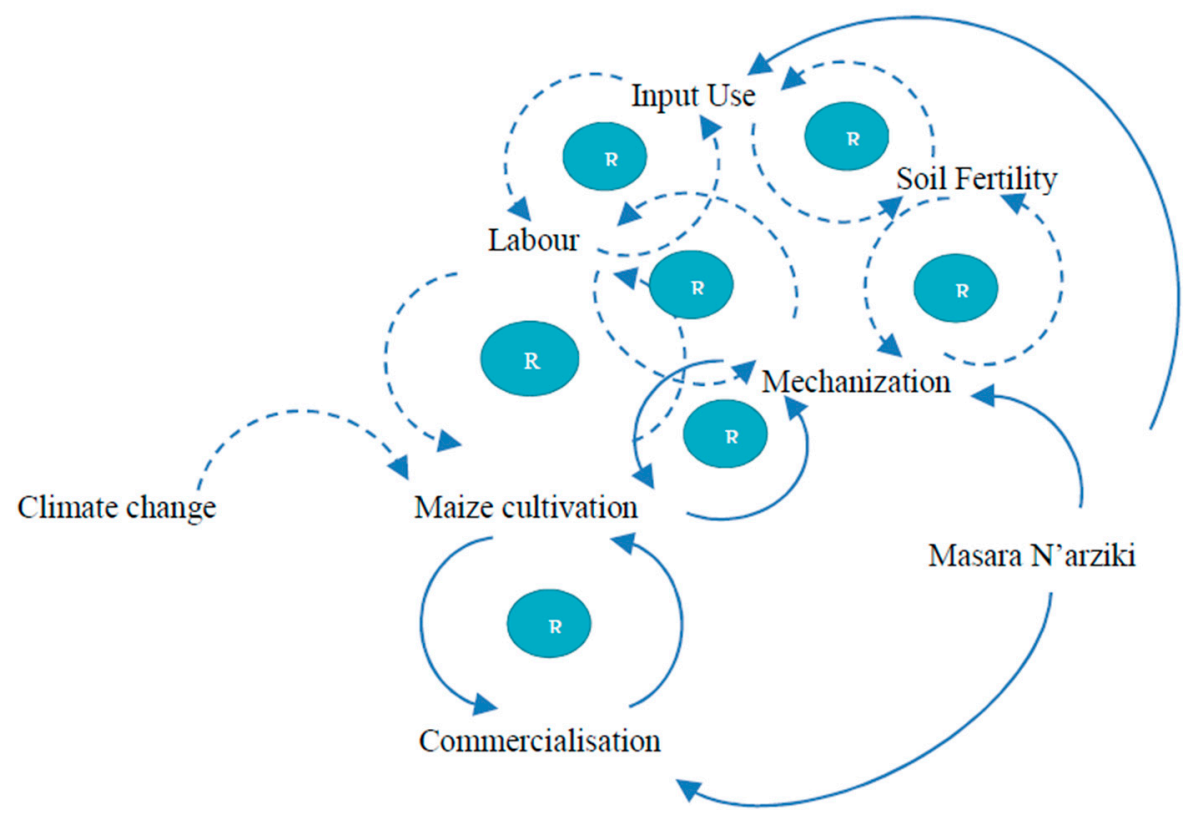

Figure 3. Causal loop diagram.

\subsubsection{Agricultural Practices}

Closely linked to the decrease of labor availability and the cultivation of maize as a commercial crop is mechanization. In only one decade, approximately since 2006, the bullock as traction animal has disappeared in Sissala East. Farmers now hire plow and tractor services. A survey of World Food program in 2008 showed that in Northern Ghana $44 \%$ of the households reported using tractor services (WFP, 2007). A number of other studies have also captured the increase in mechanized agriculture. A survey conducted by IFPRI in 2013 in four districts of the three northern regions indicates that about $95 \%$ of 173 interviewed maize farmers used hired tractor services for land preparation [96]. Data of the Ghana Living Standard Survey 2005/2006 showed that hired labor is the most costly input for farmers, accounting on average for about $50 \%$ of total input cost for a farmer in the Northern regions [99]. Fertilizer was the second most costly input, but accounted for only $21 \%$. This explains the increasing demand for labor-saving technologies, such as mechanization. Plowing can also by undertaken by animal power but animal husbandry is also relatively labor and land intensive, making it an unpopular choice in the locations where labor is already costly [99].

The trend to increased mechanization negatively impacts the poorer farmers: "The plows first attend the bigger and richer farmers, often times they arrive too late at my place, I should already have planted." (Interview). This was also found by Diao et al. [99]. A 2013 survey by IFPRI and SARI in 8 districts of five northern and central regions studied the plowing strategies of farmers. Two-third of the $60 \%$ of the surveyed farmers that plowed, hired tractor services. Among the medium and larger scale farmers who owned a tractor, $78 \%$ reported provided plowing services in the survey year.

Mechanization is also pushed by agri-businesses such as Masara N'arziki that aim to enhance productivity efficiently. Masara N'arziki for example contributed to mechanization; $96 \%$ of its farmers use tractors for plowing, as compared to $64 \%$ non-Masara farmers [89].

We identify two interaction effects: a negative interaction between labor and mechanization and a positive interaction between mechanization and maize cultivation. Both maize cultivation and mechanization are a response to labor scarcity. At the same time mechanization is also pushed by companies and development organizations aiming to support farmers to grow maize as a commercial crop. As Figure 3 shows, both loops are reinforcing. 


\subsubsection{Modern Farm Inputs}

The increasing use of fertilizer and inputs was another change highlighted. Inputs these days are widely available. In only Tumu, there are about seven agro-dealers with branches and distribution points in the surrounding villages. Additionally, input traders from elsewhere sell on the week market in Tumu.

Different key- resource persons mentioned Masara N'arziki to be the driver behind the wide availability of high quality inputs and fertilizers in Upper West region. "It was Masara N'arziki that promoted the use of inputs by providing them on credit" (Interview), and: "Several NGO's distributed inputs before, however as there was only subsistence farming, there also was little market. Masara N'arziki opened the region and input application became common practice in maize cultivation." (Interview). The success of Masara N'arzikia attracted other actors that launched similar programs (Akate farms in 2011, Kedane farms in 2012, USAID in 2014). All these contracting schemes provide farmers with inputs on credit in exchange for maize at the end of the season. Also the government encourages input use. Similar findings for other regions in Ghana are found by Houssou et al. [100]. According to Tripp and Ragassa [87] the highest concentrations of hybrid maize production is in the Upper West Region (19\% as compared to between 3 and 5 percent in Ashanti, Brong Ahafo, Northern, and Upper East Regions). The researchers attribute this to the presence of local seed company Antika and interventions such as the Masara N'arziki's program. Ragasa et al. [86] confirmed plots cultivated under contracting schemes are more likely to be treated with fertilizer and other inputs.

There is a positive interaction between the maize interventions and increased input use in general and of Masara N'arziki in particular. Participation in the scheme leads to enhanced input use.

According to the respondents there are also two other interaction effect of farm inputs: One between input use and labor and another between input use and expansion of area cultivated with maize. "Previously you needed a lot of labour to weed. 6 or 5 people to weed one acre. As such you could sometimes only grow 5 acres. Nowadays there are specialized herbicides. I don't spend time on weeding anymore, now I can cultivate up to 30 acres." (Interview). Use of herbicides and pesticides reduces the amount of labor needed to prepare and weed the land. Farmers perceive a negative and reinforcing loop between input use and labor.

Al-Hassan et al. [89] and a study of Ragasa et al. [86] both confirmed that Masara N'arziki contributed to the expansion of farmland used for maize cultivation. Masara farmers cultivate, on average 3.92 acreage, whereas non-Masara farmers grow 1.32 acreage. There is a reinforcing positive loop between input use and land expansion for maize cultivation.

\subsubsection{Natural Resources}

In all focus groups and interviews farmer reported the degradation of soils. Reasons listed were: too little crop rotation, the application of fertilizers and pesticides and the plowing practices. As one of the technical advisors mentioned: "Farmers continuously grow maize, soil fertility has decreased tremendously and as such, farmers are now dependent on fertilizer. Adding to that the application of chemicals and the deep plowing have left their traces." Houssou et al. [106,107] confirm that plowing negatively effects the structure and fertility of the soil. Masara N'arziki encouraged farmers to apply conservation farming techniques, however Al-Hassan et al. [89] found that these have not been adopted by farmers.

These findings are confirmed by Dietz et al. [108] in a study of local perceptions of development and change in Northern Ghana. The soil deterioration farmers experienced also in this study was attributed to over-cultivation and the use of chemical fertilizers. Maize cultivation has not only intensified it has also expanded. "Ten years ago millet was the dominant crop. These days it is difficult to find millet. The same counts for yam. For the energy it costs to grow one acre of millet, you can cultivate seven acres of maize." (Interview). 
In summary, according to farmers both the intensification and expansion of maize cultivation has led to decreasing soil fertility. Based on their perception we assume a negative link and a reinforcing loop between current way of maize cultivation and soil fertility.

\subsubsection{Commercialisation}

Farmers mentioned that since 2010 maize has become what can be labelled a cash crop. According to discussants Masara N'arziki opened up the region. As one farmer phrased: "With the establishment of Masara-N'arziki the isolated Upper West was opened. Masara N'arziki guaranteed a market and it became profitable and interesting to grow maize. Wienco had supply contracts with poultry farms and beer breweries." (Interview) According to Al Hassan et al. [89], 43\% of the Masara farmers cultivate maize for the market, compared to $7 \%$ of the non-Masara farmers.

Since 2010 also demand has been continuously rising, consumers in the cities of Tamale, Accra and Kumasi like the poultry industry and beer breweries strongly depend on Northern Ghana for their maize. Additionally, traders from the South have found their way up north where now they employ networks of agents buying at farm level. Farmers perceive a positive interaction between commercialization and maize cultivation.

\subsubsection{Climate}

The majority of the farmers claimed that over the last decennia rainfall has become erratic and unpredictable. As exemplified by the following quote: "Before we knew when the rains would come, now they are unpredictable. And less frequent, the droughts in between the rains last longer." (Interview). And: "When the maize is ready for fertilizer application, the rain is not there." (Interview). And: "The crop is dead before it is full-grown". (Interview). The few systematically collected meteorological data available (e.g., [109,110]; Ghana Meteorological Agency) and qualitative research studies $[77,111,112]$, confirm that the rainy season has intensified and shortened with more and longer dry spells and an increase in extreme weather events.

It is out of the scope of this study to analyze to what extent the value chain intervention affects this ongoing changing rainfall pattern. However, what is clear from the literature is that vice versa, more erratic rainfalls will most probably negatively affect maize cultivation. Compared to other crops grown in the region, maize is actually prone to droughts and erratic rainfall. Issahaku and Maharjan [113] find that reduced rainfall and temperature rises are likely to prompt farmers to switch from the cultivation of cassava and maize to the planting of sorghum, rice, and yam. In summary; maize farmers might in the future be confronted with bad harvests.

\section{Discussion: What Are the Potential Long-Term Effects of the Maize Value Chain Intervention on Local Food Security?}

Due to Masara N'arziki's investments and efforts, along with similar value chain interventions, farmers in Sissala East are now cultivating maize for markets in the South of Ghana. Different value chain analyses report effects such as increased yield, enhanced income and technology adoption. In first sight positive effects. However the longer-term implications of these effects remain unclear. With the help of a causal loop diagram, we were able to analyze how the value chain intervention interacts with the landscape. In this section, we highlight the possible consequences of the triggered or reinforced dynamics for food security in the long run.

The causal loop diagram shows many reinforcing loops; overall farmers are becoming more dependent on maize, and with the input and output markets, for sustaining their livelihood. In view of the continuously rising market demand for maize, the external push by both commercial companies and the government for agricultural modernization and the increased interest of farmers in labor extensive crops, it can be expected that maize cultivation will continue to expand and intensify.

Many of the maize value chain interventions in the area are predicated on the idea that improved yield and market linkages, lead to enhanced farmer income and as such capacity to buy food. However, 
in practice this linkage is not evident. Ragasa et al. [90] found that the higher yields and income achieved are not high enough to cover the costs of higher inputs.

Even if profits are enhanced farmers can only improve their food security situation if more food is indeed available. Even though more maize is cultivated in Sissala East, this does not automatically mean that locally enough is available for consumption. Due to enhanced market integration, a significant share of the maize grain needs of Southern Ghana had to be met by Northern markets to the subsequent higher prices in Sissala East negatively affected food deficit and food purchasing [114].

For food security also availability and accessibility of a diversity of foods is important. In Sissala East maize has replaced other crops. Interviewees mentioned that as their farming system is increasingly dominated by maize, also their diet shifts towards being more maize based. Ingredients for typical local plates such as Kenkey, Fufu and TZ are increasingly made from maize instead of sorghum and millet. As one the interviewees mentions: "Whether you like it or not, you have to eat maize. If you want beans or millet, you have to go to Burkina Faso as it is absent on the local market here".

Modern maize cultivation might align well with current farmer livelihoods in terms of labor availability, interests, and ambitions, however it will only contribute to improved food security if locally enough food is available; either through diversification of farming systems, or through diversification of market offer.

\section{Conclusions: A Systems Approach to Food Security}

In this study, we experimented with a systems approach to enrich the linear value chain analysis. By shining light on the interactions and feedback loops of the intervention with its agro and socio-economic environment, the analysis revealed that besides the positive direct outputs such as improved yield and enhanced income; farmers increased market integration might have repercussions for local food security in the long term. Unless a diversity of foods at local markets will be guaranteed, chances are high that this one-sided crop dependency results in an increased vulnerability [71]

A systems approach does not provide a recipe for how to combat food insecurity. As our assessment showed; it is complex to pinpoint the trends triggered by the feedback loops and make claims with regard to the implications on food security. Nevertheless an enhanced understanding of the interactions between the value chain and its wider context enables policy makers and practitioners to get a grasp of the longer-term implications of an intervention. Moreover, it makes it possible to identify entry points or even interventions pathways for policy that encourage food security in the long run.

We suggest development policy and practice to scrutinize ongoing trends in the agro-ecology (land use, climate), demographics (population, migration, labor), and the economy before designing an intervention targeting food security. As such, interventions become embedded in their context.

Author Contributions: E.M. and A.C.M.G.v.W.: Conceptualization, E.M.: Methodology, Validation, Investigation, Visualization, Supervision, and Project Administration, E.M.: Writing-Original Draft Preparation, E.M. and A.C.M.G.v.W.: Writing-Review \& Editing.

Funding: This research was funded by de Nederlandse Organisatie voor Wetenschappelijk Onderzoek, Food and Business Global Challenges program: W 08.250.206.

Acknowledgments: We thank Abdulahi Aliyu, Solidaridad West Africa for assistance in selecting the research area and preparing the fieldwork. We would also like to show our gratitude to Peter the Kulve, director of Operations Masara N'arziki and Natomah Kipo, supervisor Masara N'arziki for facilitating the field research and sharing their pearls of wisdom with us during the course of this research.

Conflicts of Interest: The authors declare no conflict of interest. 


\section{References}

1. Bourne, M.C. Food security: Postharvest losses. In Encyclopedia of Agriculture and Food Systems; Alfen, N.K.V., Ed.; Academic Press: Oxford, UK, 2014; pp. 338-351.

2. Gereffi, G.; Fernandez-Stark, K. Global Value Chain Analysis: A Primer; Duke Social Science Research Institute: Durham, NC, USA, 2016.

3. Dicken, P.; Kelly, P.; Olds, K.; Yeung, H.W. Chains and networks, territories and scales: Towards a relational framework for analysing the global economy. Glob. Netw. 2001, 1, 89-112. [CrossRef]

4. Gereffi, G.; Humphrey, J.; Kaplinsky, R. Introduction: Globalisation, value chains and development. IDS Bull. 2001, 32, 1-8. [CrossRef]

5. Gereffi, G.; Humphrey, J.; Sturgeon, T. The governance of global value chains. Rev. Int. Political Econ. 2005, 12, 78-104. [CrossRef]

6. Gereffi, G. Global value chains in a post-Washington Consensus world. Rev. Int. Political Econ. 2014, 21, 9-37. [CrossRef]

7. Henderson, J.; Dicken, P.; Hess, M.; Coe, N.; Yeung, H.W.C. Global production networks and the analysis of economic development. Rev. Int. Political Econ. 2002, 9, 436-464. [CrossRef]

8. Hopkins, T.; Wallerstein, I. Patterns of development of the modern world-system. Review 1977, 1, 11-145.

9. Werner, M.; Bair, J.; Fernández, V.R. Linking up to development? Global value chains and the making of a post-Washington Consensus. Dev. Chang. 2014, 45, 1219-1247. [CrossRef]

10. Ouma, S.; Boeckler, M.; Lindner, P. Extending the margins of marketization: Frontier regions and the making of agro-export markets in northern Ghana. Geoforum 2013, 48, 225-235. [CrossRef]

11. Daviron, B.; Ponte, S. The Coffee Paradox: Global Markets, Commodity Trade and the Elusive Promise of Development; Zed Books: Londen, UK, 2005.

12. Dolan, C.; Humphrey, J. Governance and trade in fresh vegetables: The impact of UK supermarkets on the African horticulture industry. J. Dev. Stud. 2000, 37, 147-176. [CrossRef]

13. Fold, N. Lead Firms and Competition in 'Bi-polar'Commodity Chains: Grinders and Branders in the Global Cocoa-chocolate Industry. J. Agrar. Chang. 2002, 2, 228-247. [CrossRef]

14. Gibbon, P.; Ponte, S. Trading Down: Africa, Value Chains, and the Global Economy; Temple University Press: Philadelphia, PA, USA, 2005.

15. Mather, C.; Greenberg, S. Market Liberalisation in Post-Apartheid South Africa: The Restructuring of Citrus Exports after 'Deregulation'. J. South. Afr. Stud. 2003, 29, 393-412. [CrossRef]

16. Muradian, R.; Pelupessy, W. Governing the coffee chain: The role of voluntary regulatory systems. World Dev. 2005, 33, 2029-2044. [CrossRef]

17. Poulton, C.; Macartney, J. Can public-private partnerships leverage private investment in agricultural value chains in Africa? A preliminary review. World Dev. 2012, 40, 96-109. [CrossRef]

18. Moseley, W.G.; Logan, B.I. Food security. In Toward a New Map of Africa; Wisner, B., Toulmin, C., Chitiga, R., Eds.; Earthscan: London, UK, 2005; pp. 133-152.

19. Lang, T. Food Security and Sustainability: The Perfect Fit; Sustainable Development Commission: London, UK, 2009.

20. Moseley, W.; Schnurr, M.; Bezner Kerr, R. Interrogating the technocratic (neoliberal) agenda for agricultural development and hunger alleviation in Africa. Afr. Geogr. Rev. 2015, 34, 1-7. [CrossRef]

21. Lang, T.; Barling, D. Food security and food sustainability: Reformulating the debate. Geogr. J. 2012, 178, 313-326. [CrossRef]

22. Sen, A. Public action to remedy hunger. Interdiscip. Sci. Rev. 1991, 16, 324-336. [CrossRef]

23. Gladwin, C.H.; Thomson, A.M.; Peterson, J.S.; Anderson, A.S. Addressing food security in Africa via multiple livelihood strategies of women farmers. Food Policy 2001, 26, 177-207. [CrossRef]

24. Valdivia, C.; Gilles, J. Gender and resource management: Households and groups, strategies and transitions. Agric. Hum. Values 2001, 18, 5-9. [CrossRef]

25. Franke, R.; Chasin, B. Seeds of Famine: Ecological Destruction and the Development Dilemma in the West African Sahel; Universe Books: Montclair, NJ, USA, 1980.

26. Watts, M.J. Silent Violence: Food, Famine, and Peasantry in Northern Nigeria; University of Georgia Press: Athens, GA, USA, 2013; Volume 15.

27. Maxwell, S.; Slater, R. Food policy old and new. Dev. Policy Rev. 2014, 21, 531-553. [CrossRef] 
28. Lindenberg, M. Measuring household livelihood security at the family and community level in the developing world. World Dev. 2002, 30, 301-318. [CrossRef]

29. Sage, C. The interconnected challenges for food security from a food regimes perspective: Energy, climate and malconsumption. J. Rural Stud. 2013, 29, 71-80. [CrossRef]

30. Carney, J.A. The bitter harvest of Gambian rice policies. Globalizations 2008, 5, 129-142. [CrossRef]

31. Moseley, W.G.; Gray, L.C. (Eds.) Hanging by a Thread: Cotton, Globalization, and Poverty in Africa; Ohio University Press: Athens, OH, USA, 2008.

32. Toenniessen, G.; Adesina, A.; DeVries, J. Building an alliance for a green revolution in Africa. Ann. N. Y. Acad. Sci. 2008, 1136, 233-242. [CrossRef] [PubMed]

33. Sanchez, P.A.; Denning, G.L.; Nziguheba, G. The African green revolution moves forward. Food Secur. 2009, 1,37-44. [CrossRef]

34. Kragelund, P. Towards convergence and cooperation in the global development finance regime: Closing Africa's policy space? Camb. Rev. Int. Aff. 2015, 28, 246-262. [CrossRef]

35. Mawdsley, E. DFID, the private sector and the re-centring of an economic growth agenda in international development. Glob. Soc. 2015, 29, 339-358. [CrossRef]

36. Epale, S.J. Plantations and Development in Western Cameroon, 1885-1975: A Study in Agrarian Capitalism; Vantage Press: Burlington, NJ, USA, 1985.

37. Glover, D.J. Contract farming and smallholder outgrower schemes in less-developed countries. World Dev. 1984, 12, 1143-1157. [CrossRef]

38. Hall, R.; Scoones, I.; Tsikata, D. Plantations, outgrowers and commercial farming in Africa: Agricultural commercialisation and implications for agrarian change. J. Peasant Stud. 2017, 44, 515-537. [CrossRef]

39. Matenga, C.R.; Hichaambwa, M. Impacts of land and agricultural commercialisation on local livelihoods in Zambia: Evidence from three models. J. Peasant Stud. 2017, 44, 574-593. [CrossRef]

40. Oya, C. Contract farming in sub-Saharan Africa: A survey of approaches, debates and issues. J. Agrar. Chang. 2012, 12, 1-33. [CrossRef]

41. Smalley, R. Plantations, Contract Farming and Commercial Farming Areas in Africa: A Comparative Review; FAC Working Paper 55; Future: Brighton, UK, 2013.

42. Vermeulen, S.; Cotula, L. Over the heads of local people: Consultation, consent, and recompense in large-scale land deals for biofuels projects in Africa. J. Peasant Stud. 2010, 37, 899-916. [CrossRef]

43. Yaro, J.A.; Teye, J.K.; Torvikey, G.D. Agricultural commercialisation models, agrarian dynamics and local development in Ghana. J. Peasant Stud. 2017, 44, 538-554. [CrossRef]

44. Birthal, P.S.; Joshi, P.K.; Gulati, A. Vertical Coordination in High-Value Commodities No. 85; International Food Policy Research Institute (IFPRI): Washington, DC, USA, 2005.

45. Chakraborty, D. Contract farming in India: Unique solution to multilayer agricultural problems? Rev. Mark. Integr. 2009, 1, 83-102. [CrossRef]

46. Pandit, A.; Lal, B.; Rana, R.K. An assessment of potato contract farming in West Bengal state, India. Potato Res. 2015, 58, 1-14. [CrossRef]

47. Ton, G.; Vellema, W.; Desiere, S.; Weituschat, S.; D'Haese, M. Contract farming for improving smallholder incomes: What can we learn from effectiveness studies? World Dev. 2018, 104, 46-64. [CrossRef]

48. Rist, L.; Feintrenie, L.; Levang, P. The livelihood impacts of oil palm: Smallholders in Indonesia. Biodivers. Conserv. 2010, 19, 1009-1024. [CrossRef]

49. Schooneveld, G.C.; German, L.A.; Nutakor, E. Land-based investments for rural development? A grounded analysis of the local impacts of biofuel feedstock plantations in Ghana. Ecol. Soc. 2011, 16. [CrossRef]

50. Maertens, M.; Swinnen, J.F. Trade, standards, and poverty: Evidence from Senegal. World Dev. 2009, 37, 161-178. [CrossRef]

51. Anderman, T.L.; Remans, R.; Wood, S.A.; DeRosa, K.; DeFries, R.S. Synergies and tradeoffs between cash crop production and food security: A case study in rural Ghana. Food Secur. 2014, 6, 541-554. [CrossRef]

52. Kuma, T.; Dereje, M.; Hirvonen, K.; Minten, B. Cash crops and food security: Evidence from Ethiopian smallholder coffee producers. J. Dev. Stud. 2018, 1-18. [CrossRef]

53. Negash, M.; Swinnen, J.F. Biofuels and food security: Micro-evidence from Ethiopia. Energy Policy 2013, 61, 963-976. [CrossRef]

54. Vicol, M. Potatoes, Petty Commodity Producers and Livelihoods: Contract farming and agrarian change in Maharashtra, India. J. Agrar. Chang. 2018. [CrossRef] 
55. Xu, Y. Politics of inclusion and exclusion in the Chinese industrial tree plantation sector: The global resource rush seen from inside China. J. Peasant Stud. 2018, 1-25. [CrossRef]

56. Tsikata, D.; Yaro, J.A. When a good business model is not enough: Land transactions and gendered livelihood prospects in rural Ghana. Fem. Econ. 2014, 20, 202-226. [CrossRef]

57. IOB. Food for thought Review of Dutch Food Security Policy 2012-2016; IOB: The Hague, The Netherlands, 2018.

58. Gómez, M.I.; Ricketts, K.D. Food value chain transformations in developing countries: Selected hypotheses on nutritional implications. Food Policy 2013, 42, 139-150. [CrossRef]

59. Graef, F.; Sieber, S.; Mutabazi, K.; Asch, F.; Biesalski, H.K.; Bitegeko, J.; Fasse, A. Framework for participatory food security research in rural food value chains. Glob. Food Secur. 2014, 3, 8-15. [CrossRef]

60. Lowitt, K.; Hickey, G.M.; Ganpat, W.; Phillip, L. Linking communities of practice with value chain development in smallholder farming systems. World Dev. 2015, 74, 363-373. [CrossRef]

61. Riisgaard, L.; Bolwig, S.; Ponte, S.; Du Toit, A.; Halberg, N.; Matose, F. Integrating poverty and environmental concerns into value-chain analysis: A strategic framework and practical guide. Dev. Policy Rev. 2010, 28, 195-216. [CrossRef]

62. Murphy, J.T.; Schindler, S. Globalizing development in Bolivia? Alternative networks and value-capture challenges in the wood products industry. J. Econ. Geogr. 2009, 11, 61-85. [CrossRef]

63. Neilson, J.; Pritchard, B. Value Chain Struggles: Institutions and Governance in the Plantation Districts of South India; John Wiley \& Sons: Hoboken, NJ, USA, 2011; Volume 93.

64. Deans, H.; Ros-Tonen, M.A.; Derkyi, M. Advanced Value Chain Collaboration in Ghana's Cocoa Sector: An Entry Point for Integrated Landscape Approaches? Environ. Manag. 2017, 62, 143-156. [CrossRef] [PubMed]

65. Reed, J.; Deakin, L.; Sunderland, T. What are 'Integrated Landscape Approaches' andhow effectively have they been implemented in the tropics: A systematic map protocol. Environ. Evid. 2015, 4. [CrossRef]

66. Folke, C.; Colding, J.; Berkes, F. Synthesis: Building resilience and adaptive capacity in social-ecological systems. Navig. Soc.-Ecol. Syst. Build. Resil. Complexity Chang. 2003, 9, 352-387.

67. Ericksen, P.J. Conceptualizing food systems for global environmental change research. Glob. Environ. Chang. 2008, 18, 234-245. [CrossRef]

68. Ericksen, P.; Stewart, B.; Dixon, J.; Barling, D.; Loring, P.; Anderson, M.; Ingram, J. The value of a food system approach. Food Secur. Glob. Environ. Chang. 2010, 25, 24-25.

69. Ingram, J. A food systems approach to researching food security and its interactions with global environmental change. Food Secur. 2011, 3, 417-431. [CrossRef]

70. UNEP. Food systems and natural resources. A report of the working group on food systems of the international resource panel; Westhoek, H., Ingram, J., Van Berkum, S., Özay, L., Hajer, M., Eds.; UNEP: Nairobi, Kenya, 2016.

71. HLPE. Nutrition and Food Systems. A Report by the High Level of Experts on Food Security and Nutrition of the Committee on World Food Security; FAO: Rome, Italy, 2017.

72. Marsden, T.; Sonnino, R. Human health and wellbeing and the sustainability of urban-regional food systems. Curr. Opin. Environ. Sustain. 2012, 4, 427-430. [CrossRef]

73. Meadows, D.H. Thinking in Systems: A Primer; Chelsea Green Publishing: Hartford, VT, USA, 2008.

74. Kasanga, R.K.; Kotey, N.A. Land Management in Ghana: Building on Tradition and Modernity; IIED: London, UK, 2001.

75. Akabzaa, T. Mining in Ghana: Implications for national economic development and poverty reduction. In Mining in Africa: Regulation and Development; Pluto Press: London, UK, 2009; pp. 25-65.

76. Acheampong, E.; Campion, B.B. Socio-economic impact of biofuel feedstock production on local livelihoods in Ghana. Ghana J. Geogr. 2013, 5, 1-16.

77. Rademacher-Schulz, C.; Schraven, B.; Mahama, E.S. Time Matters: Shifting Seasonal Migration in Northern Ghana in Response to Rainfall Variability and Food Insecurity. Clim. Dev. 2014, 6, 46-52. [CrossRef]

78. Breth, S.; Downswell, C.R. Sasakawa Africa Association, Annual Report 2002-2003; Nippon Foundation: Tokyo, Japan, 2003.

79. Al-Hassan, R.; Poulton, C. Agriculture and Social Protection in Ghana; FAC Working Paper 09; Future Agricultures Consortium: Brighton, UK, 2009.

80. Puplampu, K.P. State-NGO relations and agricultural sector development. In Critical Perspectives in Politics and Socio-Economic Development in Ghana; Tettey, W., Puplampu, K.P., Berman, B., Eds.; Brill: Leiden, The Netherlands, 2003; pp. 135-151. 
81. Amanor, K.S. From Farmer Participation to Pro-Poor Seed Markets: The Political Economy of Commercial Cereal Seed Networks in Ghana; IDS Bulletin 42; Institute of Development Studies: Oxford, UK, 2011.

82. Gage, D.; Bangnikon, J.; Abeka-Afari, H.; Hanif, C.; Addaquay, J.; Antwi, V.; Hale, A. The Market for Maize, Rice, Soy and Warehousing in Northern Ghana; Report on the EAT project; USAID: Accra, Ghana, 2012.

83. Andam, K.; Johnson, M.; Ragasa, C.; Kufoalor, D.S. A Chicken and Maize Situation: The Poultry Feed Sector in Ghana; IFPRI Discussion Paper 01601; IFPRI: Washington, DC, USA, 2016.

84. RVO. Project Plan Sustainable Maize Programme in North Ghana, Sustainable Entrepreneurship and Food Security Facility; RVO: The Hague, The Netherlands, 2009.

85. Prorustica. Masara N'arziki, 2008-2013: A Review Summary; Prorustica Ltd.: Suffolk, UK, 2013.

86. Ragasa, C.; Lambrecht, I.; Kufoalor, D.S. Limitations of contract farming as a pro-poor strategy: The case of maize outgrower schemes in upper West Ghana. World Dev. 2018, 102, 30-56. [CrossRef]

87. Tripp, R.; Ragasa, C. Hybrid Maize Seed Supply in Ghana; Ghana Strategy Support Program Working Paper, 40; IFPRI: Accra, Ghana, 2015.

88. Lambrecht, I.B.; Ragasa, C. Do development projects crowd-out private sector activities? Evidence from contract farming participation in Northern Ghana. Food Policy 2018, 74, 9-22. [CrossRef]

89. Al-Hassan, A.; Sadick, M.; Alidu, S.A. Sustainable Maize Project in the North of Ghana, Mid-Term Evaluation Final Report; University of Development Studies: Tamale, Ghana, 2016.

90. Yin, R.K. Designing case studies. In Qualitative Research Methods; Maruster, L., Ed.; Sage: Newbury Park, CA, USA, 2003.

91. Herbert, J. Testimonies of the City: Identity, Community and Change in a Contemporary Urban World; Routledge: Abbington, UK, 2016.

92. Forrester, J.W. Industrial dynamics-After the first decade. Manag. Sci. 1968, 14, 398-415. [CrossRef]

93. Meadows, D.H.; Meadows, D.L.; Randers, J.; Behrens, W.W. The Limits to Growth, a Report for the Club of Rome's Project on the Predicament of Mankind; Earth Island: London, UK, 1972.

94. Sterman, J.D. Business Dynamics: Systems Thinking and Modeling for a Complex World; Mcgraw-Hill Education: New York, NY, USA, 2000.

95. Rammelt, C.F.; Leung, M.W. Tracing the Causal Loops Through Local Perceptions of Rural Road Impacts in Ethiopia. World Dev. 2017, 95, 1-14. [CrossRef]

96. Houssou, N.; Kolavalli, S.; Bobobee, E.; Owusu, V. Animal Traction in Ghana. Ghana Strategy Support Program Working Paper No. 34; IFPRI: Accra, Ghana, 2013.

97. CSVSA. Population and Housing Census; Ghana Statistical Service: Accra, Ghana, 2012.

98. Hesselberg, J.; Yaro, J.A. An assessment of the extent and causes of food insecurity in northern Ghana using a livelihood vulnerability framework. GeoJournal 2006, 67, 41-55. [CrossRef]

99. Diao, X.; Cossar, F.; Houssou, N.; Kolavalli, S. Mechanization in Ghana: Emerging demand, and the search for alternative supply models. Food Policy 2014, 48, 168-181. [CrossRef]

100. Houssou, N.; Johnson, M.; Kolavalli, S.; Asante-Addo, C. Changes in Ghanaian farming systems: Stagnation or a quiet transformation? Agric. Hum. Values 2018, 35, 41-66. [CrossRef]

101. Kuuire, V.Z.; Mkandawire, P.; Luginaah, I.; Arku, G. Abandoning land in search of farms: Challenges of subsistence migrant farming in Ghana. Agric. Hum. Values 2016, 33, 475-488. [CrossRef]

102. MoFA. Ministry of Food and Agriculture: Pilot Program Based Budget (PBB) for 2013-2015; MoFA: Accra, Ghana, 2012.

103. Kuuire, V.Z.; Mkandawire, P.; Arku, G.; Luginaah, I. Abandoning farms in search of Food: Food remittance and household food security in Ghana. Afr. Geogr. Rev. 2013, 32, 125-139.

104. Luginaah, I.; Weis, T.; Galaa, S.; Nkrumah, M.K.; Bezner-Kerr, R.; Bagah, D. Environment, Migration and Food Security in the Upper West Region of Ghana. In Environment and Health in Sub-Saharan Africa: Managing an Emerging Crises; Luginaah, I.N., Bezner-Kerr, R., Eds.; Springer: Dordrecht, The Netherlands, 2009; pp. 25-38.

105. Van der Geest, K. “We're Managing!” Vulnerability and Response to Climate Variability and Change among Rural Households in Northwest Ghana. Master's Thesis, University of Amsterdam, Amsterdam, The Netherlands, 2002.

106. Akramov, K.; Malek, M. Analyzing Profitability of Maize, Rice, and Soybean Production in Ghana: Results of PAM and DEA Analysis; Ghana Strategy Support Program Working Paper No. 0028; IFPRI: Accra, Ghana, 2012. 
107. Houssou, N.; Diao, X.; Cossar, F.; Kolavalli, S.; Jimah, K.; Aboagye, P.O. Agricultural mechanization in Ghana: Is specialized agricultural mechanization service provision a viable business model? Am. J. Agric. Econ. 2013, 95, 1237-1244. [CrossRef]

108. Dietz, T.; Bymolt, R.; Bélemvire, A.; van der Geest, K.; de Groot, D.; Millar, D.; Zaal, F. PADev Guidebook; KIT Publishers: Amsterdam, The Netherlands, 2013.

109. Laux, P. Statistical Modelling of Precipitation for Agricultural Planning in the Volta Basin of West Africa. Ph.D. Thesis, University of Stuttgart, Stuttgart, Germany, 2009.

110. Van de Giesen, N.; Liebe, J.; Jung, G. Adapting to climate change in the Volta Basin, West Africa. Curr. Sci. 2010, 98, 1033-1038.

111. Jung, G.; Kunstmann, H. High-resolution regional climate modeling for the Volta region of West Africa. J. Geophys. Res. Atmos. 2007, 112. [CrossRef]

112. Tschakert, P.; Tutu, R.; Alcaro, A. Embodied experiences of environmental and climatic changes in landscapes of everyday life in Ghana. Emot. Space Soc. 2013, 7, 13-25. [CrossRef]

113. Issahaku, Z.A.; Maharjan, K.L. Climate change impact on revenue of major food crops in Ghana: Structural Ricardian cross-sectional analysis. In Communities and Livelihood Strategies in Developing Countries; Springer: Tokyo, Japan, 2014; pp. 13-32.

114. Hjelm, L.; Dasori, W. Comprehensive Food Security and Vulnerability Analysis: Focus on Northern Ghana. World Food Program; Ghana Statistical Service and Ministry of Food and Agriculture: Accra, Ghana, 2012.

(C) 2018 by the authors. Licensee MDPI, Basel, Switzerland. This article is an open access article distributed under the terms and conditions of the Creative Commons Attribution (CC BY) license (http://creativecommons.org/licenses/by/4.0/). 